\title{
Cervical Neuroendocrine Carcinoma
}

National Cancer Institute

\section{Source}

National Cancer Institute. Cervical Neuroendocrine Carcinoma. NCI Thesaurus. Code C128045.

A malignant, high grade neuroendocrine neoplasm that arises from the cervix. This category includes small cell and large cell neuroendocrine carcinoma. 